\title{
OLD-AGE BENEFITS AND RETIREMENT DECISIONS OF RURAL ELDERLY IN BRAZIL
}

\author{
Irineu Evangelista de Carvalho Filho ${ }^{b}$
}

First version: June 1999 - This version: December 1, 2002

\begin{abstract}
:
I estimate the impact of social security benefits on retirement decisions of rural workers by studying changes in the rules governing social security in Brazil. I focus on a 1991 reform, which brought a reduction in the minimum eligibility age for males and females, a doubling of benefit values and the extension of benefits to non-heads of households. Because beneficiaries are not subject to means or retirement tests, I estimate a pure income effect. I find that a reduction in the minimum eligibility age for old-age benefits was an important determinant in the reduction in labor supply of elderly rural workers in Brazil. Finally, I find that benefit take-up rates are larger among the better educated, but least-schooled workers show the largest labor supply responses to the reform.
\end{abstract}

\footnotetext{
${ }^{2}$ This paper is an adaptation of Chapter 1 of my Ph.D. Thesis. Financial support from CNPq, the National Institute of Aging, the Center for Retirement Research at Boston College and the Schultz Fund at MIT is thankfully acknowledged. I am grateful to my advisors Josh Angrist, Daron Acemoglu, Abhijit Banerjee, Dora Costa and Esther Duflo for their comments at different stages of this paper. Special thanks go to Dora Costa for crucial support during all stages of this project. Marcos Chamon in particular and participants at the MIT Labor/Public Finance Seminar and Labor, Development Economics and Econometrics lunches and Georgetown University and Bowdoin College seminars also deserve thanks for their inputs to this project. Errors are mine.

${ }^{b}$ For comments and suggestions, please contact me at carvalho@mit.edu
} 
Population estimates by the United Nations indicate that $56 \%$ of the world's 65 and over population lived in developing countries in $1990 .^{1}$ Moreover, the elderly proportion share of the population is increasing in most developing countries, due to gains in longevity. The aging of developing countries' populations raises concerns about the living conditions of their elderly, especially in countries where incipient development has already weakened traditional family links or strong filial piety motives are not emphasized. With the aging of developing countries' populations, social security arrangements may be called for where they are not already in place.

The introduction or expansion of transfer programs for the elderly has several consequences on the labor market equilibrium. Perhaps the most salient of them are changes in the labor supply patterns of the elderly. The challenge for policymakers is to design systems that do not create excessive burden on workers and employers, particularly social security systems that do not generate too large an impact on the labor supply of the elderly and dependency ratios.

Because developing countries differ from developed countries in a variety of ways, the accumulated knowledge from studies of social security based on developed countries might be of limited relevance. ${ }^{2}$ Moreover, there are only few studies about retirement decisions in developing countries. ${ }^{3}$

Sources of differences between developed and developing countries include the differences in income levels, in the stringency of credit constraints, in the relative importance of non-market activities, in the capital intensity in production, in workers' life expectancy, and in the importance of the informal, undocumented sector. 
Factors such as small asset holdings, low lifetime income, poorer health and likely poor access to leisure opportunities suggest that working as long as one's body permits may be the more common strategy among the rural elderly in developing countries.

On the other hand, low capital intensity in rural activities may cause work to be particularly arduous and degrading for elderly people. Previous evidence from developed countries suggests that income effects for low-income are larger than income effects for high-income workers. ${ }^{4}$ Evidence from developed countries suggests that relatively few workers retire before they become eligible for social security (Kahn 1988; Johnson 1999), perhaps because of credit constraints. Because the development of the financial sector is positively correlated with income levels (Levine 1997), the connection between the minimum eligibility age to benefits and the usual retirement age might be stronger in developing countries.

The Brazilian social security reform of 1991 reduced the minimum eligibility age for rural old-age benefits for men from 65 to 60 , increased the minimum benefit paid to rural old-age beneficiaries from $50 \%$ to $100 \%$ of the minimum wage, extended old-age benefits to female rural workers who were not heads of households, and reduced the age at which women qualified for benefits from 65 to 55 . This reform provides a unique opportunity to study the effect of benefits on retirement in developing countries for three reasons.

First, because Brazilian rural beneficiaries are not subject to either an earnings test or retirement requirement, hence the decision to apply for a rural old-age benefit is not strategic - as a reasonable first approximation, one does not need to model a dynamically optimizing view of retirement incentives (unlike Stock and Wise (1990)). 
Second, because eligibility for rural benefits depends only on predetermined characteristics of workers and there are no means or retirement tests, the effects of increases in benefits or extension of eligibility in this program generates a pure income effect.

Third, the structure of the reform allows for the use of instrumental variables for income from benefits, in a way that address problems such as measurement errors in the benefits variable (relevant in a high inflation country) and omitted variables bias.

In this paper, I am able to use changes in rules governing eligibility and benefit values in the old-age program for rural workers to identify the effect of old-age benefits on male elderly labor supply. These changes in rules and benefit values provide me with an exogenous source of variation in benefits that is not correlated with a worker's idiosyncratic preferences for work. I first use a differences-in-differences-in-differences (triple differences) approach, where I compare changes in benefit take-up rates and labor variables for rural and urban workers of different age groups. Then, I move to structural estimation of the parameter of interest. The gradual build-up of benefit take-up rates, the change in the minimum eligibility age, the differential increase in benefits for rural workers, and the rule changes affecting female workers all provide me with a set of instrumental variables capturing exogenous variation in social security benefits. In addition, because benefit take-up rates may be correlated with factors that enhance labor market performance, such as ability or education, I analyze the differences in take-up rates and labor supply responses across education groups.

I find results consistent with the pension reform causing a sizeable contraction in the labor supply of the affected rural elderly. Instrumental variables estimates imply that a 
$\mathrm{R} \$ 100$ increase in benefits increases the probability that workers "did not work in the reference week" by 15.0 percentage points; receipt of benefits increases the same probability by 45.2 percentage points. Those estimates imply elasticities of labor force non-participation with respect to benefit values and to benefit receipt equal to 0.65 and 0.70 respectively - a large figure compared to the evidence from developed countries (e.g. Krueger and Pischke (1992)). I also find that benefit take-up rates are larger among the better educated, but that least-schooled workers change their labor supply the most.

Section 1 summarizes the reform, describes the data, our outcomes of interest and sample selection choices. Section 2 presents the identification strategy; triple differences estimates using age, time and occupation variation; and presents graphs that summarize the evidence on the first-stage relationship. Section 3 presents triple difference estimates for benefit take-up rates and labor responses. Section 4 presents instrumental variables estimates of the effect of benefits on labor supply and how they differ across different educational groups. Section 5 concludes discussing the results and their implications for policy.

\section{The 1991 Reform in the Brazilian Social Security System}

The Brazilian Constitution of 1988 established the guidelines for a reform of the Social Security system, to be regulated by ordinary law. Those guidelines require, among other things, that rural workers' old-age benefits be extended to women who were not household heads; that length-of-service eligibility be extended to rural workers; that no benefit be smaller than one minimum wage; and that the minimum age for old-age social security eligibility for rural workers be reduced. 
Male rural workers were affected by: (1) a reduction in the minimum eligibility age from 65 to 60 ; (2) an increase in benefits from $50 \%$ to $100 \%$ of a minimum wage; and, (3) extension of access to length-of-service benefits (see Table 1). Female rural workers were affected by: (1) a reduction in the minimum eligibility age from 65 to 55 ; and, (2) the end of the one person-per-household restriction, which allowed married females to take-up benefits too.

The reform went into effect when the necessary Ordinary Law was passed in July 24, 1991 (Lei \#8212/8213). After that, the increase in the value of outstanding benefits went automatically into effect, but actual extension of benefits to newly eligible workers took a few months to be processed for a variety of reasons (administrative delay, distance to the nearest post office, lack of information about entitlements and others).

The timing of the events can be summarized as follows: In 1988, the Constitutional change was passed and more informed workers became aware of their new entitlements to be implemented. In July 1991, the necessary ordinary law was passed, with benefit payments to rural beneficiaries of old-age pensions increasing automatically from 50 to in general 100 percent of the minimum wage and newly eligible rural workers (60 to 64 year olds) beginning to apply for benefits. In September 1992, the month of reference of the 1992 household survey that I will use in estimation, take-up of new benefits was still incomplete, either for bureaucratic reasons or because of delays in the spread of information. Finally, by September 1993, the month of reference of the 1993 survey, almost all of the take-up process was completed and newly eligible workers were already receiving their benefits. Administrative data from the Anuário Estatistico da Previdencia (1997) confirms this pattern of sluggish take-up: by the end of $1992,129,953$ newly 
eligible males aged 60-64 were receiving rural old age benefits; by the end of 1993, 326,158 were; by the end of 1994 that figure was 358,761 .

The last year before the Constitutional change was passed for which the survey data is available is 1987. Data is available also for 1988 and 1989. The latest year before the actual implementation of the reform for which data is available is 1990 . There are no data for 1991. In 1992, old-age benefits have already increased and take-up of new benefits is still partial, which allows us to take advantage of additional time variation in take-up rates. In 1993, the take-up process is almost "complete". There are no data for 1994. The earliest year after the take-up process has been "completed" for which data is available is 1995.

The reform described above provides exogenous variation in social security benefits, which will be used to estimate the effect of those benefits on labor supply. Figure 1 shows the time series of the flow of new pension benefits. Although the change in the law happened in July 1991, there does not seem be any increase in the flow of granted benefits per year before 1992. The spike in the number of granted old-age benefits lasted until 1994 (Anuário Estatístico da Previdência (1998)). The yearly amount of new disability benefits shrinks after the reform implementation, suggesting that disability and old-age benefits are substitutes for the age group affected by the reform. The number of granted rural length-of-service benefits is only about $0.5 \%$ of all rural benefits and is hardly visible in the picture. Therefore, the impact of the extension of access to length-ofservice pensions is likely to be small or negligible.

To a first approximation, social security for rural workers has a flat benefit schedule. Before the reform, rural old-age benefits were flat and equal to $50 \%$ of the minimum 
wage. Therefore, rural workers had no incentive to postpone their application to benefits. Since the reform, the same formula for calculation of urban workers' benefits applies, which is a function of documented past earnings. However, because the vast majority of rural workers do not have a long history of documented earnings, nearly $100 \%$ of rural beneficiaries are at the comer, receiving exactly the minimum benefit equal to $100 \%$ of the minimum wage. (Appendix Table 2 shows that the average old-age benefit in 1997 was $\mathrm{R} \$ 121.37$, while the minimum wage was $\mathrm{R} \$ 120$ ).

It is worthwhile noting that aposentadorias rurais (rural pensions) contain no incentives for total withdrawal from the labor force. There is no earnings test and, unlike their urban counterparts, rural workers do not have to quit their jobs to become eligible for benefits ${ }^{5}$. Therefore, examining only discrete measures of labor supply (as is common for studies of retirement in the United States) might miss the adjustment in the intensity margin, captured by total hours.

I use the Pesquisa Nacional por Amostra de Domicilios (PNAD) to estimate the impact of the extension of social security benefits on labor supply. The PNAD is a yearly household survey, with sample size equal to $1 / 500$ of the Brazilian population (about 100,000 households) and is designed to produce a picture of the living conditions and economic life of the Brazilian population, rural and urban. For every individual I observe characteristics such as age, race, education, school enrollment, income from different sources, housing and living arrangements, family structure, work, fertility, migration and other topics. I observe various measures of labor participation, including hours of work, labor force non-participation and earnings. Table 2 reports means for some relevant variables for different years, age groups and occupation groups 
The labor supply measures that I use should capture different features of the retirement decision in the population of interest. The basic binary indicator of retirement decision is the variable "did not work in the week of reference". To explore the intensity of work, I use total hours per week.

Unfortunately, the data do not allow me to determine the type of social security benefits paid to each beneficiary. The PNAD classifies social security benefits into somewhat broad categories. It only differentiates between aposentadorias (disability, old age and length of service benefits) and pensões (military and survivors' income maintenance benefits). Pensões are mostly received by widows whose husbands were covered by social security benefits.

In my baseline specification, I identified rural and urban workers based on their occupations. I observe every worker's current occupation and I observe past occupation up to a four years recall. ${ }^{6}$ Individuals who do not report their occupation or who have not worked in the last 4 years are classified as having "undefined" occupation. My results are not sensitive to the use of location of residence as a proxy for occupation for those workers whose occupation is undefined, or to the assignment of urban occupation for all workers with undefined occupation. ${ }^{7}$

In the econometric analysis of this paper, I restrict myself to male workers age 50-69, either unmarried or whose wives are not older than 50 . The compulsory retirement age for public sector workers in Brazil was 70 during the period of the study. Because very few $(<0.5 \%)$ elderly rural workers had 12 years of schooling or more - equivalent to high school completion or more - while the same figures for elderly urban workers are $9 \%, I$ 
restrict both the rural and urban samples to workers who had less than 12 years of schooling.

\section{Identification Strategy}

I identify the effects of the reform on labor supply by exploring a legislated exogenous variation over time in benefits availability, take-up rates and benefit values. The reform of social security in question, passed in 1991, made male rural workers age 60-64 eligible to old-age benefits, while benefits paid out to all eligible male rural workers - including the already eligible 65 years old or older - doubled.

Eligibility to rural benefits is based on age, occupational history and whether the observation pertains to the period before or after the reform. I can therefore use this information to infer benefit eligibility for each observation in the sample, formed by a time series of cross-sections of a representative annual household survey.

The results in this paper will be presented first as triple differences estimates, without controlling for characteristics other than age, occupation and year of observation; then regression estimates with controls; then IV estimates where functions of age, occupation and year of observation are used as instruments for benefit receipt or benefit amount received.

\subsection{Triple Differences Strategy}

The comparison between changes in outcomes for a group affected by the reform (treated group) and a group unaffected (control group) is at the heart of differences-indifferences estimates. Let subscripts T, C, Post and Pre denote respectively treated group, control group, after and before the reform. Let $\mathrm{L}$ denote the outcome of interest, say, 
labor force participation. Let the change in the outcomes of the treated group be $\Delta \mathrm{L}_{\mathrm{T}}$ or ( $\mathrm{L}_{T, \text { Post }}-\mathrm{L}_{\mathrm{T}, \mathrm{Pre}}$ ). This change may be due to the changes in the social security rules those workers are facing, but also for other time specific factors that affect also the control group. If those time specific factors are additive, they can be "differenced away" with the subtraction of the change in outcomes for the control group, $\Delta \mathrm{L}_{\mathrm{C}}$, from $\Delta \mathrm{L}_{\mathrm{T}}$. The differences-in-differences estimate for the impact of the reform is $D D=\left(\Delta L_{T}-\Delta L_{C}\right)=$ $\left(L_{T, \text { Post }}-L_{T, P r e}\right)-\left(L_{C, \text { Post }}-L_{C, \text { Pre }}\right)$. For instance, for the group aged 60-64, rural workers were affected by the reform, whereas urban workers were not. Hence, comparing the outcome of interest changed differently across rural and urban workers would provide a differences-in-differences estimate.

The idea is to use the trend for the control group to construct a counterfactual to the reform for the treated group. The identification condition is that there is no shock to the relative labor market outcomes of the treatment and control groups contemporaneous to the reform. That may be a strong identification assumption, after all, there are observable and unobservable differences between the treated and the control group that may account for relative shifts in the outcomes of interest.

One can control for different relative shocks that might have affected rural and urban workers of all ages by moving to a triple-differences framework. This strategy consists of using a "unaffected" pair of "treated" and "control" groups, with characteristics similar to the relevant treated and control group in the "affected" pair, but for which the treatment did not take place. The key to this approach is in the similarities in the "affected" and "unaffected" pairs. The groups in the "unaffected" pair are going to be used to difference away any relative trend in the treated and control groups correlated with unobservable 
variables, but not due to the intervention. Hence, if subscripts A and U denote "affected" and "unaffected", the triple-differences estimates are obtained from the subtraction of the differences-in-differences estimates based on the "non-affected" pair from the differences-in-differences estimates based on the "affected" pair, i.e.,

$$
D D D=D D_{A}-D D_{U}=\left(\Delta L_{T}-\Delta L_{C}\right)_{A}-\left(\Delta L_{T}-\Delta L_{C}\right)_{U}
$$

For instance, the age groups 55-59 and 65-69 were, if anything, less affected by the reform than the age group 60-64. The difference in changes in outcomes across rural and urban workers aged 60-64 is the differences-in-differences for the "affected" group or $D D_{A}$. The difference in changes in outcomes across rural and urban workers aged 55-59 or 65-69 is the differences-in-differences for the "unaffected" group or $D D_{U}$.

\subsection{Regression Interpretation}

Triple-differences estimates have a regression interpretation: triple differences estimates can also be obtained as the coefficient on the interaction between AFTER, $R U R A L$ and a dummy for the affected age group, TREAT, after controlling for the effects of all combinations between any two of the variables above.

For example:

$$
\begin{aligned}
Z=\alpha_{0}^{z}+ & \alpha_{1}^{z} A F T E R+\alpha_{2}^{z} R U R A L+\alpha_{3}^{z} T R E A T+\beta_{1}^{z}(T R E A T \times R U R A L) \\
& +\beta_{2}^{Z}(A F T E R \times T R E A T)+\beta_{3}^{z}(R U R A L \times A F T E R) \\
& +\beta_{Z}(A F T E R \times R U R A L \times T R E A T)+v \\
Y=\alpha_{0}+ & \alpha_{1} A F T E R+\alpha_{2} R U R A L+\alpha_{3} T R E A T+\beta_{1}(T R E A T \times R U R A L) \\
& +\beta_{2}(A F T E R \times T R E A T)+\beta_{3}(R U R A L \times A F T E R) \\
& +\beta_{Y}(A F T E R \times R U R A L \times T R E A T)+v
\end{aligned}
$$

In equation (2), $Z$ is the receipt of social security benefits. In (3), $Y$ is the labor supply outcome of interest. In both equations, $R U R A L$ is a fixed occupation effect, $A F T E R$ is a 
fixed year effect, and TREAT is a dummy for the age group that was treated by the program change ( 1 if treatment group, 0 if control group). The coefficient $\beta_{1}$ controls for secular differences between rural and urban male workers in the treated age group. The coefficient $\beta_{2}$ controls for the time trend specific to the age group (aged 60-64) affected by the reform. The coefficient $\beta_{3}$ controls for the time trend specific to all rural workers. The coefficient $\beta_{Z}\left(\beta_{Y}\right)$ on the interaction of age, location, and year is the triple difference estimate and identifies the impact of the reform on benefit receipt (labor supply). The triple difference estimator has the interpretation of a reduced form estimate, capturing the effect of the rule change on the group means of the outcome variable. Moreover, the ratio $\beta_{\mathrm{Y}} / \beta_{\mathrm{Z}}$ is numerically equal to the instrumental variables estimate of the effect of benefit receipt on labor supply when I use the triple interaction term as the instrument for the benefit variable.

\subsection{Instrumental Variables Strategy}

The triple-differences estimates described in the previous sections are reduced form estimates and do not control for other determinants beyond occupation, age and year effects. The structural model I want to estimate is:

$\mathrm{Y}=\beta_{\mathrm{own}}$ OwnBenefits $+\phi_{1}$ (age, occupation, time) $+\mathrm{X} \delta+v$

In the equation above, $\phi_{1}$ denotes a full set of age, occupation, time, age-occupation, age-time and occupation-time effects and $\mathrm{X}$ is a set of other control variables.

The existence of correlation between $v$ and the benefit variables, i.e., between the heterogeneity in preferences towards labor force participation and the benefit variables, causes OLS estimates to be biased. 
One source for this bias may be differences in the actual access to benefits across workers with different levels of ability. To receive benefits, a worker has to establish his eligibility through a bureaucratic process that requires proofs of age, occupation and in some cases past contributions to the Social Security system. More able or more educated workers may have an advantage because they are more likely to work in the formal sector or more able to understand the rules of the game. In this case, if ability is positively correlated with preferences for work, then OLS estimates of the effect of benefits on labor supply will be biased downwards. If workers with less attachment to their labor force participation are the ones more involved in gathering information about benefits entitlements (or preemptively organizing the necessary documents), then it will be the case they will be the first ones in the queue for receiving newly granted benefits. In this case, the OLS bias will go in the opposite direction: it would generate an upward bias (in absolute terms) in the parameter that measures the effect of the benefit.

Measurement errors in benefit values are another source of bias in the OLS estimates. The Brazilian economy suffered from very high inflation rates during the period studied in this paper and this could have created confusion about the nominal values of benefits (readjusted monthly through part of this period) in a survey where respondents self-report the level and composition of their income.

The solution to this problem is the use of instrumental variables. A valid instrument for benefit receipt is a variable that has no effect on the outcome of interest but for its effect on the benefit measure. Benefit values are determined by either the minimum wage or complicated functions of a worker's past earnings. Eligibility for benefits is a function 
of observed variables like occupation and age and variables not observed by the econometrician such as health status.

I constructed instruments for benefit values, which incorporate variation in age, time and occupation. The interaction between rural workers, age 60-64 and after-period will instrument for the increases in benefits accruing to the 60-64 rural males who became eligible to old-age benefits with the reform. To take into account the gradual character of the changes caused by the reform, this instrument can be interacted with an indicator for both years after the reform: 1992 and 1993. The interaction between rural workers, age 65 and up and after period will instrument for the increases in the value of old-age benefits from $50 \%$ to $100 \%$ of the minimum wage occurred in 1991 affecting old-age beneficiaries already in the benefit payroll.

\section{Triple Differences: Results}

\subsection{Benefit Take-Up Rates}

Table 3 shows the difference-in-difference-in-differences estimates of the effect of the social security eligibility extension on rural workers age 60-64 benefits take-up rates. Here I compare workers with rural and urban occupations, observed before and after the reform, respectively in 1990 and 1993. I restrict my sample to workers with less than 12 years of schooling and who are either unmarried or with spouses younger than 50 , i.e., those whose spouses are too young to be strongly affected by the reform. ${ }^{8}$ The top panel compares the change in receipt of benefits for 60-64-year-old workers with rural occupations to the ones with urban occupations. Each cell contains the proportion of respondents who received any kind of social security benefits for the relevant group 
represented in the axes, along with standard errors of the means. The point estimates in Table 3 show that the change in aposentadorias benefit take-up rates for rural workers aged 60-64 ("affected" group) was 23.59 percentage points larger than that of their urban counterparts during the period immediately before and after the reform. The same statistic for the "unaffected" groups was only -0.91 percentage points for the 55-59 years old and 6.27 percentage points for the 65-69 years old, both statistically insignificant. Therefore, the triple differences in the aposentadorias benefit take-up rates of by the targeted group increased 24.50 (17.32) percentage points, when I use 55-59 (65-69) yearolds as the "unaffected" group.

Table 4 presents similar estimates for average benefit receipts. Rural males aged 60-64 became eligible for old-age benefits with the reform. Between 1990 and 1993, their average benefits increased from $\mathrm{R} \$ 12.72$ to $\mathrm{R} \$ 101.57$ (in Reais of September of 1997). For the same age group, but with urban occupations, average benefits increased from $R \$ 91.00$ to $R \$ 151.98$, yielding average benefits for rural workers increased $R \$ 27.87$ more than for urban workers during the period of study, not statistically different from zero. In the central panel of Table 4, there are the estimates for the "unaffected" group of 55-59 years old, whose eligibility status did not change, showing a difference-indifferences of negative $\mathrm{R} \$ 25.13$, statistically not different from zero. This "unaffected" 55-59 age group allows me to control for trends over time in benefits differentials between rural and urban areas. The difference between the two difference-in-differences estimates is the triple differences estimate equal to $\mathrm{R} \$ 53.60$, with a t-statistic of 1.59 . In the bottom panel of Table 4, there are the estimates for the "unaffected" group of 65-69 years old, showing a difference-in-differences $\mathrm{R} \$ 59.40$, with a t-statistic of 1.61 . 
Remember that the eligibility status of males age 65-69 did not change with the reform, but their old-age benefits, originally set equal to $1 / 2$ minimum wage, increased to one minimum wage. This result suggests that despite the doubling of rural benefits measured in terms of the minimum wage, rural workers seem to have lagged behind urban workers in terms of changes in the level of their benefits. The implied triple difference estimates by comparing the $60-64$ and $65-69$ age groups is negative $R \$ 31.53$, not statistically distinguishable from zero.

The triple differences estimates of the effect of the reform on the outcomes of interest can be made more precise with the inclusion of additional controls in a regression framework. Table 6 presents the coefficients on the interaction between rural occupation, post-reform dummies and affected age group in a regression with controls age, rural/urban and year effects, and all second level interactions between those variables. I also present results for two sub-samples related to educational levels: some schooling and no schooling. The estimates on column (1) of Table 6 imply that as a consequence of the reform, benefit take-up rates for rural males aged $60-64$ rose gradually by 12.1 and 34.0 percentage points, respectively in 1992 and 1993, compared to a counterfactual with no reform. The estimates in columns (2)-(3) show that benefit take-up rates increased significantly faster and by a larger amount for elderly males with some schooling than for the ones with no schooling. The estimates of the effects of the reform on monthly benefits, reported on columns (4)-(6), show a qualitatively similar pattern of larger increases in monthly benefits for rural workers with some schooling.

The results above suggest an important role for education as an enabler of access to social programs, perhaps because more educated workers have better access to 
information, are more likely to understand their rights and entitlements, and are more likely to have the necessary documentation.

\subsection{Labor Force Effects}

Table 5 presents the triple differences estimates for the variable "did not work week of reference". Those results are typical of all other labor supply outcomes we analyzed and will not report for brevity. The proportion of rural workers aged 60-64 who did not work in the week of reference increased statistically and economically significant 9.48 percentage points more than the figures for urban workers of the same age, during the period immediately before and after the reform.

This finding is likely caused by the reform in question, because for the "unaffected" groups, no such differential in behavior between rural and urban workers was found. The differences-in-differences estimates were statistically insignificant -1.28 and 2.88 percentage points respectively for the "unaffected" groups aged 55-59 and 65-69 years.

Therefore, triple-differences estimates imply that there was a statistically significant 10.76 or 6.60 percentage points increase in the proportion of rural workers aged $60-64$ who "did not work in the week of reference", depending on the choice of the "unaffected" group.

The ratio of the triple difference estimates for the effect of the reform on "did not work in the week of reference" and the "benefit take-up rates" is consistent with an IV estimate of the marginal effect of benefit take-up rates on labor participation in the 30 $40 \%$ range, depending on the "unaffected" group of choice.

\subsection{Visual Interpretation}

Figure 2 provides a visual interpretation of the identification strategy. It displays the age benefit take-up profiles for males in rural and urban areas in five different years: 
1984, long before the reform was thought of; 1987, right before the Constitutional change; 1990, right before the passing of the ordinary law implementing the changes; 1992, right after the program starts; and 1993, when the reform is likely to have full effects.

For rural area males, there is a remarkable increase in benefit take-up in 1992 and 1993 for the cohorts age 61 to 64 , which can be observed in the top left graph of Figure 2. The age benefit take-up profiles for all years before 1992 have a similar shape: there is a steep increase by age 65 , the pre-reform eligibility age for rural old-age benefits, and take-up rates approach $100 \%$ for the older old. The implementation of the reforms shifted the age at which a 50\% male benefit take-up rate is achieved in the rural area from $65-66$ to 61 . For urban area males, age benefit take-up profiles show a smooth increase in takeup rates with age, which can be explained by a large proportion of urban workers receiving "length-of-service" benefits. The absence of a noticeable spike in the distribution of ages at which urban workers take up benefits can be explained by the accumulation of years of documented work at different rates, due to different unemployment and informal work spells and different ages of first entry at the labor force. More importantly for the identification strategy, there does not seem to be any remarkable change in the age benefit take-up profiles of urban workers.

Figure 3 shows the age average benefit receipts profiles for rural and urban dwellers, before and after the reform. It presents a noticeable increase in average benefit receipt for rural dwellers age 60 and older in 1992 and especially 1993. All other movements in the age benefits profiles are parallel in the sense of affecting either all age groups or both rural and urban workers. ${ }^{10}$ 


\section{IV: Results}

Table 7 reports the OLS and IV estimates of the coefficient of "benefit receiver" dummy and "monthly benefits" levels on three labor outcomes: "did not work in the reference week", "total hours per week" and "monthly earnings".

I find that OLS estimates are in general smaller in absolute value than IV estimates for all dependent variables, and more so for monthly benefits. The difference between IV and OLS estimates in this case may be due to measurement error in the benefit variables and correlation between benefit values and preferences for work - but because this difference is wider for likely poorly measured monthly benefits, measurement error seems to play a central role.

Instrumental variables estimates imply that receipt of an "aposentadoria" benefit causes an increase in the probability of not working in the reference week of 45.2 percentage points, a reduction in the hours worked per week of 25.2 hours and a reduction of monthly earnings of $-\mathrm{R} \$ 632$. Workers with some schooling reduce their labor supply less than the ones with no schooling - e.g. their reduction in labor participation was 12.8 percentage points smaller than for workers with no schooling. However the effects on monthly earnings are greater for workers with some schooling after all, workers with some schooling earn more per hour than the ones with no schooling.

Instrumental variables estimates confirm a similar pattern for the effects of monthly benefits: $\mathrm{R} \$ 100$ of benefits are found to increase the probability of not working in the reference week by 15.0 percentage points, to reduce hours worked per week by 8.5 hours, 
and to reduce monthly earnings by $-\mathrm{R} \$ 317$. Differences across workers of different educational levels show a larger participation and hours response among workers with no schooling and a larger monthly earnings reduction among the ones with some schooling.

Different labor responses to benefits across educational groups may have arisen for a variety of reasons: more educated workers may have access to more capital - which can make their tasks at work less physically demanding; also, for a given flat benefit, more educated workers will have lower replacement rates because they have greater earning potential.

\section{Conclusions}

The reform in the Brazilian social security system in 1991 provides an opportunity to learn about labor supply responses to: reductions in the minimum eligibility age for oldage benefits, increases in benefit levels, and about how social programs reach groups with different education levels in developing countries.

This paper estimates a pure income effect - the vast majority of the existing literature has estimated total effects that are the sum of an income and a substitution effect, the latter due to means, income, earnings or retirement tests. In the standard case of leisure as a normal good, the income and substitution effects of means tested unearned income point to the same direction. All else being equal, one should expect smaller total effects in the program analyzed in this paper than if means testing were in place.

However, this paper shows that a reduction in the minimum eligibility age for old age benefits had remarkably strong consequences on the work behavior of those affected. Because in this paper estimates are based on a comparison between the just-made-eligible 
by the reform (elderly age 60-64) with the soon-to-be-eligible (elderly age 55-59), its estimates are likely an underestimate of the actual responses.

The results show that elderly rural workers in Brazil are more strongly responsive to benefit income than elderly workers in developed countries. Instrumental variables estimates suggest that each unit of monthly benefits displaces 3.1 units of earned income - despite the fact that that is a pure income effect. The large estimate for the effect of current benefits on earnings can be explained by substitution of non-remunerated activities, such as subsistence agriculture, unpaid work and leisure, for wage earning and remunerated activities. ${ }^{11}$ Another factor explaining this remarkable sensitivity to benefit income might well be the smaller riskiness of benefit income relative to the typical income volatility of a rural worker in a developing country.

The main policy lesson from this paper is that governments should proceed with caution in the implementation of social security programs or other distributive policies, taking into account the possibility of substantial output losses. Of course, this recommendation includes neither efficiency nor equity judgments, but only an observation about the costs likely to be incurred with the implementation of such programs. Furthermore, if labor markets are characterized by high unemployment or nonparticipation rates of the youths and those non-employed fill the vacancies open by the retired elderly, output losses due to retirement may be minimized. Evaluating the effect of this reform on the employment rates of youths is an interesting undertaking for future research.

This paper also shows that more educated workers are better able to take advantage of social programs than less educated ones, perhaps because either they are more able to 
understand the formal rules of the game or because they are better informed in general. Given that this program of rural pensions is widely viewed as a program very successful in targeting the poor (Filgueiras 1998), this result suggests that governments in developing countries should put more effort into making their social programs as universal as possible. Otherwise, scarce resources will be spent, without really achieving the most basic equity goal: reaching for the ones that need the most.

\section{BIBLIOGRAPHY}

Barroso Leite, Celso, 1978. Social Security in Brazil, International Social Security Review, 31, 318-329.

Cardoso de Oliveira, M.V., 1961. Social Security in Brazil, International Labor Review, 84, 376-393.

Carvalho, Irineu, 2000. Old-Age Benefits and the Labor Supply of Rural Elderly in Brazil - mimeo.

Case, Anne and Angus Deaton, 1998. Large Cash Transfers to the Elderly in South Africa, Economic Journal; vol. 108 n450, pp. 1330-61.

Chiarelli, Carlos, 1976. Social Security for Rural Workers in Brazil, International Labour Review; v113 n2 March-April 1976, pp. 159-69.

Cook, T. D. and Campbell, D. T., 1979. Quasi-Experimentation: Design and Analysis Issues for Field Settings, Chicago: Rand McNally.

Delgado, Guilherme Costa et alli, 1999. Avaliacao Socioeconômica e Regional da Previdência Social Rural - Fase II, Relatório Parcial dos Primeiros Resultados para a Região Sul do Brasil, IPEA, Brasília.

Filgueiras, Otto, 1998. Os Credores do Brasil, Teoria e Debate n³9 (nov/dec/jan 1998).

Hausman, Jerry, 1985. Taxes and Labor Supply, Handbook of Public Economics, vol. 1, ed. Alan Auerbach and Martin Feldstein.

Heckman, James and Joseph Hotz, 1989. Choosing among Alternative Nonexperimental Methods for Estimating the Impact of Social Programs: The Case of Manpower Training, Journal of the American Statistical Association, v84 n408 December 1989, pp. 862-74. 
Johnson, Richard, 1999. The Effect of Social Security on Male Retirement: Evidence from Historical Cross-Country Data, mimeo Harvard.

Krueger, Alan and Jörn-Steffen Pischke, 1992. The Effect of Social Security on Labor Supply: A Cohort Analysis of the Notch Generation, Journal of Labor Economics 10, no.4:412-37.

Levine, Ross, 1997. Financial Development and Economic Growth: Views and Agenda, Journal of Economic Literature; v35 n2 June 1997, pp. 688-726.

Malloy, James M., 1979. The Politics of Social Security in Brazil, The University of Pittsburgh Press.

Mesa-Lago, Carmelo, 1989. Social Security in Latin America and the Caribbean: a Comparative Assessment, in Ahmad, Drèze, Hills and Sen, Social Security in Developing Countries, Clarendon Press.

Meyer, Bruce, 1995. Natural and Quasi-Experiments in Economics, Journal of Business and Economics Statistics, April 1995, Vol. 13, No. 2.

Stock, James and David A. Wise, 1990. Pensions, the Option Value of Work, and Retirement, Econometrica 58(5):1151-1180.

The World Bank, 1994. Averting the Old Age Crisis, Oxford University Press. 
Table 1

Characteristics of the Brazilian Social Security System Before and After the Reform

\begin{tabular}{|c|c|c|c|}
\hline Occupation & Programs & The System Before the Reform & Changes with the Reform \\
\hline \multirow[t]{4}{*}{$\begin{array}{l}\text { Rural } \\
\text { Workers }\end{array}$} & Old-Age & $\begin{array}{l}\text { Eligibility at age } 65+\text {, rural work documented for } 1 \text { of past } 3 \text { years. } \\
\text { Only } 1 \text { person per household is eligible. } \\
\text { Benefit is flat and equal to } 50 \% \text { of the minimum wage. } \\
\text { No restriction on gainful work. } \\
\text { No bonus for deferment of pension receipt. } \\
\text { No need to quit the current job to apply for benefits. } \\
\text { No earnings/retirement test after that }\end{array}$ & $\begin{array}{l}\text { Minimum age for eligibility reduced to } 60 \text { for males and } 55 \text { for } \\
\text { females. } \\
\text { No restriction in the number of receivers in a household. } \\
\text { Benefit is } 70 \% \text { of earnings-based benefit plus } 1 \% \text { for each } 12 \text { past } \\
\text { payment of the payroll tax, up to } 100 \% \text {. Minimum benefit is } \\
\text { increased to } 100 \% \text { of the minimum wage. }\end{array}$ \\
\hline & $\begin{array}{l}\text { Length-of- } \\
\text { Service }\end{array}$ & Not available for rural workers. & Same rules as urban workers. \\
\hline & Disability & $\begin{array}{l}\text { Available at any age. Needs to stop working altogether. } \\
\text { Benefit is flat and equal to } 50 \% \text { of the minimum wage }\end{array}$ & $\begin{array}{l}\text { Benefit is } 80 \% \text { of earnings-based benefit plus } 1 \% \text { for each } 12 \text { past } \\
\text { payment of the payroll tax, up to } 100 \% \text {. Minimum benefit is } \\
\text { increased to } 100 \% \text { of the minimum wage. }\end{array}$ \\
\hline & Old-Age & $\begin{array}{l}\text { Eligibility at age } 70 \text {. Benefit is } 90 \% \text { of minimum wage. } \\
\text { Needs to quit the current job to apply for benefits. No } \\
\text { earnings/retirement test after that }\end{array}$ & $\begin{array}{l}\text { Benefit is } 70 \% \text { of earnings-based benefit plus } 1 \% \text { for each } 12 \text { past } \\
\text { payment of the payroll tax, up to } 100 \% \text {. } \\
\text { Minimum benefit increased to } 100 \% \text { of the minimum wage. }\end{array}$ \\
\hline \multirow[t]{2}{*}{$\begin{array}{l}\text { Urban } \\
\text { Workers }\end{array}$} & $\begin{array}{l}\text { Length-of- } \\
\text { Service }\end{array}$ & $\begin{array}{l}\text { Eligibility after } 30 \text { years of declared documented work. } \\
\text { Full benefits after } 35 \text { years of documented work. } \\
\text { Fewer years for some types of work. } \\
\text { No minimum age requirement. } \\
\text { Benefits determined by years of documented work and recent labor } \\
\text { earnings. Generous benefits for public sector work. } \\
\text { Minimum benefit is } 90 \% \text { of the minimum wage } \\
\text { Bonus for continued work beyond maximum eligibility period. } \\
\text { Needs to quit the current job to apply for benefits. No } \\
\text { earnings/retirement test after that. }\end{array}$ & $\begin{array}{l}\text { Minimum eligibility for females reduced to } 25 \text { years of service. } \\
\text { Benefit is } 70 \% \text { of earnings-based benefit at the minimum eligibility } \\
\text { age plus } 6 \% \text { for each additional year of service beyond it, up to } \\
100 \% \text {. } \\
\text { Minimum benefit increased to } 100 \% \text { of the minimum wage. }\end{array}$ \\
\hline & Disability & $\begin{array}{l}\text { Available at any age. Needs to stop working altogether. } \\
\text { Benefit is } 90 \% \text { of minimum wage. }\end{array}$ & $\begin{array}{l}\text { Benefit is } 80 \% \text { of earnings-based benefit plus } 1 \% \text { for each } 12 \text { past } \\
\text { payment of the payroll tax, up to } 100 \% \text {. Benefits are no less than } \\
100 \% \text { of the minimum wage. }\end{array}$ \\
\hline
\end{tabular}

Notes: The reform in the Social Security was prompted by the specification of entitlements in the Constitution promulgated in 1988. The actual implementation of the reform was delayed until ordinary Law was approved in July of 1991. Benefit increases were implemented automatically; however granting of new benefits to newlyentitled beneficiaries in general took a few months to happen, due to administrative delays in the application and grant process. 
TABLE 2

TABLE OF MEANS, ALL MALES AGED 55-64

\begin{tabular}{|c|c|c|c|c|c|c|c|c|c|}
\hline \multirow{2}{*}{$\begin{array}{l}\text { Age } \\
\text { Occupation }\end{array}$} & \multicolumn{3}{|c|}{ 55-59 } & \multicolumn{3}{|c|}{$60-64$} & \multicolumn{3}{|c|}{$65-69$} \\
\hline & URBAN & RURAL & UNDEF & URBAN & RURAL & UNDEF & URBAN & RURAL & UNDEF \\
\hline \multicolumn{10}{|l|}{1989} \\
\hline Benefit Take-up & 0.250 & 0.078 & 0.900 & 0.326 & 0.139 & 0.928 & 0.639 & 0.653 & 0.947 \\
\hline Benefit Values & 199.97 & 27.93 & 606.15 & 290.58 & 35.83 & 744.24 & 396.50 & 78.22 & 608.91 \\
\hline Worked Week of reference & 0.843 & 0.949 & 0.000 & 0.789 & 0.925 & 0.000 & 0.683 & 0.810 & 0.000 \\
\hline Total Hours / Week & 41.51 & 47.94 & 0.00 & 38.54 & 44.40 & 0.00 & 31.44 & 37.24 & 0.00 \\
\hline Monthly Earnings & 1027.21 & 492.84 & 0.00 & 915.64 & 562.64 & 0.00 & 692.61 & 522.11 & 0.00 \\
\hline Rural Location & 0.092 & 0.712 & 0.081 & 0.091 & 0.708 & 0.078 & 0.096 & 0.689 & 0.144 \\
\hline \multicolumn{10}{|l|}{1990} \\
\hline Benefit Take-up & 0.250 & 0.075 & 0.919 & 0.332 & 0.104 & 0.918 & 0.670 & 0.722 & 0.946 \\
\hline Benefit Values & 175.84 & 12.40 & 533.04 & 220.72 & 32.22 & 474.87 & 298.57 & 59.40 & 474.12 \\
\hline Worked Week of reference & 0.837 & 0.941 & 0.000 & 0.792 & 0.918 & 0.000 & 0.707 & 0.779 & 0.000 \\
\hline Total Hours / Week & 40.61 & 47.77 & 0.00 & 38.22 & 46.17 & 0.00 & 32.90 & 36.24 & 0.00 \\
\hline Monthly Earnings & 648.41 & 382.03 & 0.00 & 585.25 & 328.49 & 0.00 & 423.73 & 230.73 & 0.00 \\
\hline Rural Location & 0.098 & 0.706 & 0.069 & 0.100 & 0.691 & 0.077 & 0.125 & 0.704 & 0.133 \\
\hline \multicolumn{10}{|l|}{1992} \\
\hline Benefit Take-up & 0.247 & 0.111 & 0.901 & 0.345 & 0.307 & 0.909 & 0.677 & 0.749 & 0.957 \\
\hline Benefit Values & 132.00 & 30.59 & 446.91 & 160.46 & 64.55 & 371.33 & 205.93 & 114.66 & 397.76 \\
\hline Worked Week of reference & 0.837 & 0.907 & 0.000 & 0.809 & 0.835 & 0.000 & 0.723 & 0.739 & 0.000 \\
\hline Total Hours / Week & 40.36 & 46.64 & 0.00 & 39.49 & 42.84 & 0.00 & 34.05 & 34.58 & 0.00 \\
\hline Monthly Earnings & 576.26 & 282.33 & 0.00 & 518.28 & 217.15 & 0.00 & 402.02 & 192.12 & 0.00 \\
\hline Rural Location & 0.060 & 0.628 & 0.050 & 0.063 & 0.614 & 0.056 & 0.066 & 0.587 & 0.084 \\
\hline \multicolumn{10}{|l|}{1993} \\
\hline Benefit Take-up & 0.275 & 0.145 & 0.899 & 0.354 & 0.543 & 0.914 & 0.686 & 0.824 & 0.944 \\
\hline Benefit Values & 236.37 & 53.64 & 652.19 & 251.36 & 120.87 & 635.27 & 363.85 & 185.45 & 566.98 \\
\hline Worked Week of reference & 0.809 & 0.895 & 0.000 & 0.821 & 0.830 & 0.000 & 0.665 & 0.742 & 0.000 \\
\hline Total Hours / Week & 38.98 & 45.41 & 0.00 & 39.00 & 39.97 & 0.00 & 30.95 & 34.09 & 0.00 \\
\hline Monthly Earnings & 718.15 & 333.76 & 0.00 & 649.00 & 320.55 & 0.00 & 562.71 & 269.07 & 0.00 \\
\hline Rural Location & 0.061 & 0.633 & 0.055 & 0.062 & 0.579 & 0.065 & 0.060 & 0.601 & 0.074 \\
\hline
\end{tabular}

Notes: Urban and rural occupations are only defined for workers who had a job in the last four years before the survey. All other respondents are labeled as undefined. 
TABLE 3

TRIPLE DIFFERENCES ESTIMATES: Benefits Take-Up Rates

\begin{tabular}{|c|c|c|c|}
\hline Location/year & $\begin{array}{c}\text { Before law } \\
\text { change: } 1990\end{array}$ & $\begin{array}{c}\text { After law } \\
\text { change: } 1993 \\
\end{array}$ & $\begin{array}{l}\text { Time difference } \\
\text { for occupation }\end{array}$ \\
\hline \multicolumn{4}{|c|}{ A. Treatment Individuals: Males, 60-64 Years Old: } \\
\hline Rural Occupation & $\begin{array}{c}0.1130 \\
(0.0189)\end{array}$ & $\begin{array}{c}0.4213 \\
(0.0260)\end{array}$ & $\begin{array}{c}0.3083 \\
(0.0321)\end{array}$ \\
\hline Urban Occupation & $\begin{array}{c}0.2163 \\
(0.0192)\end{array}$ & $\begin{array}{c}0.2887 \\
(0.0206)\end{array}$ & $\begin{array}{c}0.0724 \\
(0.0282)\end{array}$ \\
\hline Occupation difference at a point in time: & $\begin{array}{r}-0.1033 \\
(0.0270)\end{array}$ & $\begin{array}{c}0.1326 \\
(0.0332)\end{array}$ & \\
\hline Difference-in-difference: & \multicolumn{2}{|c|}{$\begin{array}{c}0.2359 \\
(0.0428)\end{array}$} & \\
\hline $\begin{array}{l}\text { B: Control Group: Males, } 55-59 \text { Years Old: } \\
\text { Rural Occupation }\end{array}$ & $\begin{array}{c}0.0827 \\
(0.0128)\end{array}$ & $\begin{array}{c}0.0930 \\
(0.0128)\end{array}$ & $\begin{array}{c}0.0103 \\
(0.0181)\end{array}$ \\
\hline Urban Occupation & $\begin{array}{c}0.1963 \\
(0.0137)\end{array}$ & $\begin{array}{c}0.2157 \\
(0.0134)\end{array}$ & $\begin{array}{c}0.0194 \\
(0.0192)\end{array}$ \\
\hline Occupation difference at a point in time: & $\begin{array}{l}-0.1135 \\
(0.0187)\end{array}$ & $\begin{array}{l}-0.1227 \\
(0.0185)\end{array}$ & \\
\hline Difference-in-difference: & \multicolumn{2}{|c|}{$\begin{array}{l}-0.0091 \\
(0.0264)\end{array}$} & \\
\hline DDD & \multicolumn{2}{|c|}{$\begin{array}{c}0.2450 \\
(0.0503)\end{array}$} & \\
\hline $\begin{array}{l}\text { C: Control Group: Males, } 65-69 \text { Years Old: } \\
\text { Rural Occupation }\end{array}$ & $\begin{array}{c}0.6655 \\
(0.0349)\end{array}$ & $\begin{array}{c}0.7247 \\
(0.0279)\end{array}$ & $\begin{array}{c}0.0592 \\
(0.0447)\end{array}$ \\
\hline Urban Occupation & $\begin{array}{c}0.5898 \\
(0.0354)\end{array}$ & $\begin{array}{c}0.5864 \\
(0.0325)\end{array}$ & $\begin{array}{c}-0.0034 \\
(0.0481)\end{array}$ \\
\hline Occupation difference at a point in time: & $\begin{array}{c}0.0757 \\
(0.0498)\end{array}$ & $\begin{array}{c}0.1383 \\
(0.0429)\end{array}$ & \\
\hline Difference-in-difference: & \multicolumn{2}{|c|}{$\begin{array}{c}0.0627 \\
(0.0657)\end{array}$} & \\
\hline DDD & \multicolumn{2}{|c|}{$\begin{array}{c}0.1732 \\
(\mathbf{0 . 0 7 8 3})\end{array}$} & \\
\hline
\end{tabular}

Notes: Cells contain the aposentadoria (disability, old-age and length-of-service benefits) benefit take-up rates for the group identified. Standard errors are given in parentheses. Difference-in-difference-in-difference (DDD) is the difference-in-difference from the upper panel minus that in the lower panel. Occupation is measured by current occupation or in the case of workers without a current occupation, on latest occupation using in a recall period no longer than 4 years. Sample consists of males with less than 12 years of education, either single or with spouses 50 or younger. 


\section{TABLE 4}

TRIPLE DIFFERENCES ESTIMATES: Average Benefit Receipts

\begin{tabular}{|c|c|c|c|}
\hline Location/year & $\begin{array}{l}\text { Before law } \\
\text { change: } 1990\end{array}$ & $\begin{array}{c}\text { After law } \\
\text { change: } 1993\end{array}$ & $\begin{array}{l}\text { Time difference } \\
\text { for occupation }\end{array}$ \\
\hline \multicolumn{4}{|c|}{ A. Treatment Individuals: Males, $60-64$ Years Old: } \\
\hline Rural Occupation & $\begin{array}{l}12.72 \\
(3.58)\end{array}$ & $\begin{array}{r}101.57 \\
(11.42)\end{array}$ & $\begin{array}{l}88.85 \\
(11.97)\end{array}$ \\
\hline Urban Occupation & $\begin{array}{c}91.00 \\
(18.01)\end{array}$ & $\begin{array}{l}151.98 \\
(17.16)\end{array}$ & $\begin{array}{c}60.98 \\
(24.88)\end{array}$ \\
\hline Occupation difference at a point in time: & $\begin{array}{l}-78.27 \\
(18.36)\end{array}$ & $\begin{array}{l}-50.40 \\
(20.62)\end{array}$ & \\
\hline Difference-in-difference: & \multicolumn{2}{|c|}{$\begin{array}{c}27.87 \\
(27.61)\end{array}$} & \\
\hline $\begin{array}{l}\text { B: Control Group: Males, } 55-59 \text { Years Old: } \\
\text { Rural Occupation }\end{array}$ & $\begin{array}{l}14.41 \\
(4.76)\end{array}$ & $\begin{array}{l}26.09 \\
(4.57)\end{array}$ & $\begin{array}{r}11.68 \\
(6.60)\end{array}$ \\
\hline Urban Occupation & $\begin{array}{c}99.55 \\
(13.49)\end{array}$ & $\begin{array}{r}136.95 \\
(12.33)\end{array}$ & $\begin{array}{c}37.41 \\
(18.28)\end{array}$ \\
\hline Occupation difference at a point in time: & $\begin{array}{r}-85.13 \\
(14.31)\end{array}$ & $\begin{array}{l}-110.86 \\
(13: 15)\end{array}$ & \\
\hline Difference-in-difference: & \multicolumn{2}{|c|}{$\begin{array}{l}-25.73 \\
(19.43)\end{array}$} & \\
\hline DDD & \multicolumn{2}{|c|}{$\begin{array}{r}53.60 \\
(33.77)\end{array}$} & \\
\hline \multicolumn{4}{|l|}{ C: Control Group: Males, $65-69$ Years Old: } \\
\hline Rural Occupation & $\begin{array}{l}47.17 \\
(3.58)\end{array}$ & $\begin{array}{r}151.22 \\
(11.23)\end{array}$ & $\begin{array}{l}104.05 \\
(11.79)\end{array}$ \\
\hline Urban Occupation & $\begin{array}{l}150.15 \\
(28.93)\end{array}$ & $\begin{array}{r}194.80 \\
(19.54)\end{array}$ & $\begin{array}{c}44.65 \\
(34.91)\end{array}$ \\
\hline Occupation difference at a point in time: & $\begin{array}{l}-102.97 \\
(29.15)\end{array}$ & $\begin{array}{l}-43.57 \\
(22.54)\end{array}$ & \\
\hline Difference-in-difference: & & & \\
\hline DDD & & & \\
\hline
\end{tabular}

Notes: Cells contain the average benefit receipts for the group identified. Standard errors are given in parentheses. Difference-in-difference-in-difference (DDD) is the difference-in-difference from the upper panel minus that in the lower panel. Occupation is measured by current occupation or in the case of workers without a current occupation, on latest occupation using in a recall period no longer than 4 years. Sample consists of males with less than 12 years of education, either single or with spouses 50 or younger. 
TABLE 5

TRIPLE DIFFERENCES ESTIMATES: Did not Work in the Week of Reference

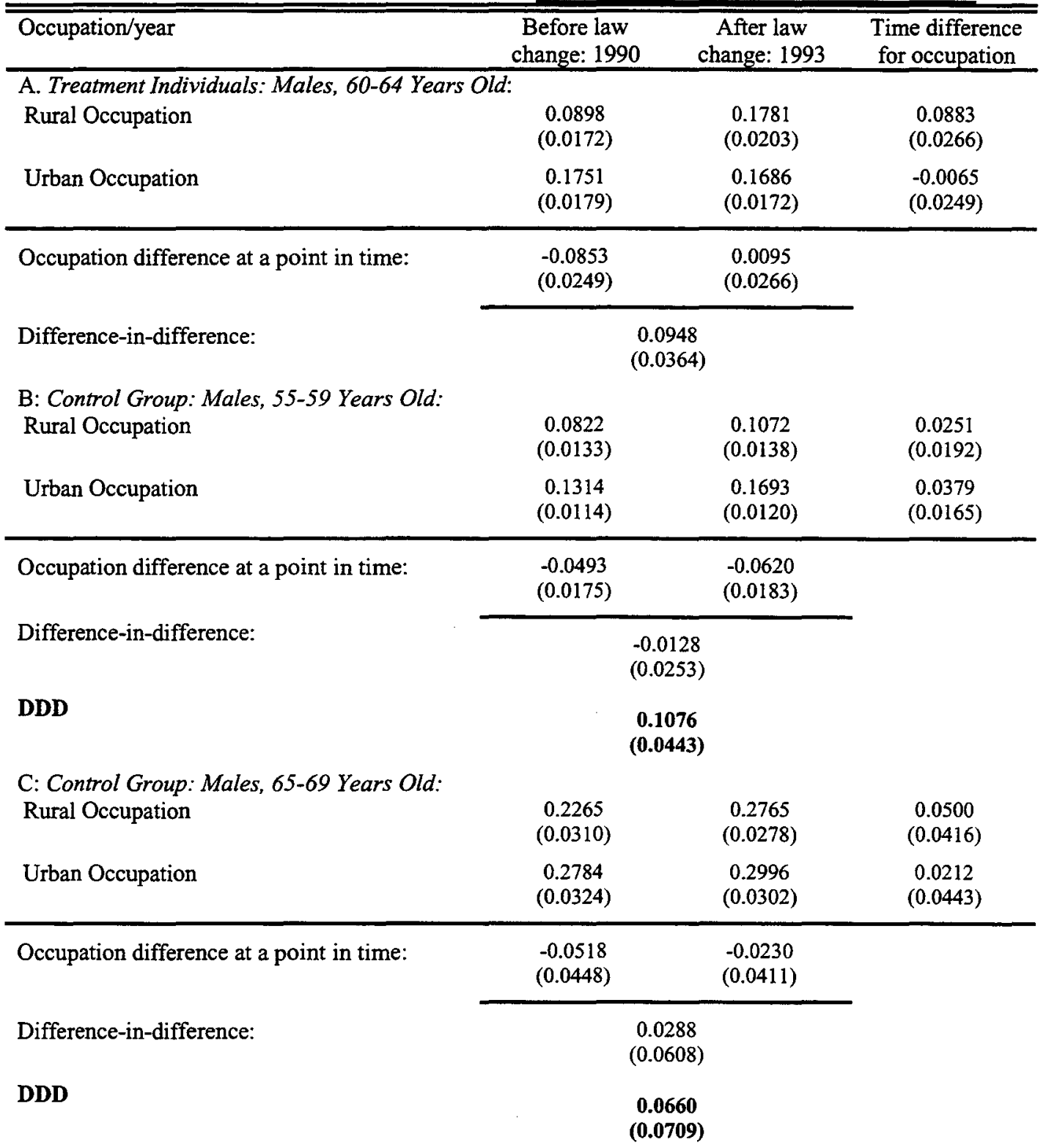

Notes: Cells contain the share of respondents who did not work in the week of reference for the group identified. Standard errors are given in parentheses; sample sizes are given in square brackets. Difference-in-difference-indifference (DDD) is the difference-in-difference from the upper panel minus that in the lower panel. Occupation is measured by current occupation or in the case of workers without a current occupation, on latest occupation using in a recall period no longer than 4 years. Sample consists of males with less than 12 years of education, either single or with spouses 50 or younger. 
TABLE 6

FIRST-STAGE REDUCED FORM ESTIMATES OF MONTHLY BENEFIT VALUES

Benefits $=\Sigma$ treat $_{\mathrm{i}} \beta_{\mathrm{i}}+\mathrm{X} \delta+\phi_{1}($ age, occupation, time $)+v$

\begin{tabular}{|c|c|c|c|c|c|c|}
\hline \multirow[t]{2}{*}{ Dependent Variables } & \multicolumn{3}{|c|}{ BENEFITS TAKE-UP RATES } & \multicolumn{3}{|c|}{ MONTHLY BENEFITSIIC4】 } \\
\hline & (1) & (2) & (3) & (4) & $\overline{(5)}$ & (6) \\
\hline Independent Variables & All & $\begin{array}{c}\text { Some } \\
\text { Schooling }\end{array}$ & $\begin{array}{c}\text { No } \\
\text { Schooling }\end{array}$ & All & $\begin{array}{l}\text { Some } \\
\text { Schooling }\end{array}$ & $\begin{array}{c}\text { No } \\
\text { Schooling }\end{array}$ \\
\hline RURAL X AGE 60-64 X YEAR 92 & $\begin{array}{c}0.121 \\
(0.021)^{* *}\end{array}$ & $\begin{array}{c}0.153 \\
(0.032)^{* *}\end{array}$ & $\begin{array}{c}0.068 \\
(0.031)^{*}\end{array}$ & $\begin{array}{c}0.558 \\
(0.271)^{*}\end{array}$ & $\begin{array}{c}0.812 \\
(0.468)\end{array}$ & $\begin{array}{c}0.015 \\
(0.075)\end{array}$ \\
\hline RURAL X AGE 60-64 X YEAR 93 & $\begin{array}{c}0.340 \\
(0.021)^{* *}\end{array}$ & $\begin{array}{c}0.390 \\
(0.031)^{* *}\end{array}$ & $\begin{array}{c}0.244 \\
(0.031)^{* *}\end{array}$ & $\begin{array}{c}0.934 \\
(0.268)^{* *}\end{array}$ & $\begin{array}{c}1.112 \\
(0.460)^{*}\end{array}$ & $\begin{array}{c}0.224 \\
(0.074)^{* *}\end{array}$ \\
\hline RURAL X AGE 65-69 X AFTER & $\begin{array}{c}0.025 \\
(0.020)\end{array}$ & $\begin{array}{c}-0.002 \\
(0.031)\end{array}$ & $\begin{array}{c}0.061 \\
(0.028)^{*}\end{array}$ & $\begin{array}{c}1.214 \\
(0.258)^{* *}\end{array}$ & $\begin{array}{c}1.691 \\
(0.459)^{* *}\end{array}$ & $\begin{array}{c}0.379 \\
(0.068)^{* *}\end{array}$ \\
\hline $\begin{array}{l}\mathbf{R}^{2} \\
\mathbf{N}:\end{array}$ & $\begin{array}{c}53131 \\
0.24\end{array}$ & $\begin{array}{c}35258 \\
0.19\end{array}$ & $\begin{array}{c}17873 \\
0.36\end{array}$ & $\begin{array}{c}53131 \\
0.07\end{array}$ & $\begin{array}{c}35258 \\
0.06\end{array}$ & $\begin{array}{c}17873 \\
0.20\end{array}$ \\
\hline
\end{tabular}

Controls: $\phi_{1}$ contains all year, age, occupation, year-age, year-occupation and age-occupation effects.

Additional Controls: X contains dummy for literacy, number of people in the household, and its square, dummy for head of household, rural location. education dummies, region dummies and the interaction between region and year dummies.

Sample: Years $89,90,92,93$. Sample of males, either single or married to a spouse younger than 50 , aged 50 to 70 , with less than 12 years of schooling and who are currently working or have been working for the last 4 years.

Notes: Social security benefits are measured in Reais of September of 1997 . I measure the permanent portion of social security benefits using information on their adjustments to inflation and the level of inflation in a 12 months window around the month of reference as discussed in the Data Appendix.

$\left({ }^{*}\right)$ denotes significance at the $5 \%$ level; $\left({ }^{* *}\right)$ denotes significance at the $1 \%$ level. 
TABLE 7

\section{STRUCTURAL ESTIMATES OF THE EFFECT OF BENEFITS ON RETIREMENT DECISIONS \\ $Y=\beta_{\text {own }}$ Benefits $+\phi_{1}$ (age, occupation, time) $+X \delta+v$}

Panel 1: DEPENDENT VARIABLE: DID NOT WORK IN REFERENCE WEEK

\begin{tabular}{|c|c|c|c|c|c|c|}
\hline & (1) & (2) & $\begin{array}{l}\text { (3) } \\
\text { IV }\end{array}$ & $\begin{array}{l}(4) \\
\text { OLS }\end{array}$ & (5) & (6) \\
\hline Benefit receiver & 0.303 & 0.452 & 0.499 & & & \\
\hline Some Schooling X Benefit Receiver & $(0.006)$ & $(0.126)$ & $\begin{array}{l}(0.126) \\
-0.128 \\
(0.046)\end{array}$ & & & \\
\hline Monthly benefits, in R $\$ 100$ of 1997 & & & & $\begin{array}{c}0.027 \\
(0.001)\end{array}$ & $\begin{array}{c}0.150 \\
(0.059)\end{array}$ & $\begin{array}{c}0.198 \\
(0.055)\end{array}$ \\
\hline $\begin{array}{l}\text { Some Schooling X Monthly Benefits, in } \\
\text { R\$100 of } 1997\end{array}$ & & & & & & $\begin{array}{l}-0.109 \\
(0.033)\end{array}$ \\
\hline
\end{tabular}

Panel 2: DEPENDENT VARIABLE: TOTAL HOURS OF WORK IN ALL JOBS

\begin{tabular}{|c|c|c|c|c|c|c|}
\hline & (1) & (2) & (3) & (4) & (5) & (6) \\
\hline & OLS & IV & IV & OLS & IV & IV \\
\hline Benefit receiver & $\begin{array}{l}-16.97 \\
(0.31)\end{array}$ & $\begin{array}{l}-25.23 \\
(6.95)\end{array}$ & $\begin{array}{l}-26.71 \\
(6.94)\end{array}$ & & & \\
\hline Some Schooling X Benefit Receiver & & & $\begin{array}{c}5.58 \\
(2.52)\end{array}$ & . & & \\
\hline Monthly benefits, in R $\$ 100$ of 1997 & & & & $\begin{array}{l}-1.48 \\
(0.04)\end{array}$ & $\begin{array}{r}-8.49 \\
(3.30)\end{array}$ & $\begin{array}{l}-10.84 \\
(3.20)\end{array}$ \\
\hline $\begin{array}{l}\text { Some Schooling X Monthly Benefits, in } \\
\mathrm{R} \$ 100 \text { of } 1997\end{array}$ & & & & & & $\begin{array}{l}5.18 \\
(1.94)\end{array}$ \\
\hline
\end{tabular}

Panel 3: DEPENDENT VARIABLE: MONTHLY EARNINGS IN REAIS OF SEPT 1997

\begin{tabular}{|c|c|c|c|c|c|c|}
\hline & (1) & (2) & (3) & (4) & (5) & (6) \\
\hline & OLS & IV & IV & OLS & IV & IV \\
\hline Benefit receiver & $\begin{array}{l}-251.08 \\
(22.72)\end{array}$ & $\begin{array}{l}-632.34 \\
(514.60)\end{array}$ & $\begin{array}{l}-509.92 \\
(516.51)\end{array}$ & & & \\
\hline Some Schooling X Benefit Receiver & & & $\begin{array}{l}-293.52 \\
(187.31)\end{array}$ & & & \\
\hline Monthly benefits, in R\$100 of 1997 & & & & $\begin{array}{l}-16.76 \\
(2.69)\end{array}$ & $\begin{array}{c}-317.26 \\
(190.43)\end{array}$ & $\begin{array}{c}-222.42 \\
(228.31)\end{array}$ \\
\hline $\begin{array}{l}\text { Some Schooling X Monthly Benefits, in } \\
\text { R\$100 of } 1997\end{array}$ & & & & & & $\begin{array}{l}-86.01 \\
(137.87)\end{array}$ \\
\hline
\end{tabular}

Controls: $\phi_{1}$ contains all year, age, occupation, year-age,, year-occupation and age-occupation effects.

Additional Controls: $\mathrm{X}$ contains dummy for literacy, number of people in the household, and its square, dummy for head of household, rural location, education dummies, region dummies and the interaction between region and year dummies.

Instruments used: For columns (2) and (5), instruments are the triple interactions rural*age $6064^{*}$ year 92 ,

rural*age6064*year93 and rural*age65up*after. For columns (3) and (6), I add the interactions between a dummy for some schooling and the triple interactions instruments used mentioned above.

Sample size: 26848 for Panels 1 and 3; 26825 for Panel 2. 


\section{Appendix A: Background information on the Brazilian Social Security system}

As in other Latin American countries, the development of social security in Brazil occurred in piecemeal fashion (Mesa-Lago (1989), Malloy (1979)), with the more powerful and organized urban occupational groups ${ }^{12}$ rewarded with earlier social security coverage than the typically less politically active rural workers. By the mid-sixties, practically all Brazilian urban workers were eligible to social security entitlements based on length-of-service, old age or disability.

The first nationwide introduction of the welfare state to Brazilian rural workers - defined as workers in occupations directly related to agriculture, ranching, forestry, fishing or small-scale mining - happened in 1967 with the establishment of the FUNRURAL (Rural Workers' Assistance Fund). The FUNRURAL was set to work drawing up contracts with hospitals all over the country in order to obtain free medical care for rural workers, with the local peasant organizations responsible for the local management of the funds. ${ }^{13}$ In 1971 , the institution of the PRORURAL (Rural Worker's Assistance Program) made rural workers eligible for social security benefits. Under that program, rural workers were entitled to disability and old age benefits for workers 65 or older (unlike urban workers who also had access to length-of-service benefits). Despite the difficult access to many parts of the Brazilian hinterland, the PRORURAL program achieved high rates of benefit take-up, especially due to the pre-existent organizational structure laid out by the FUNRURAL (Chiarelli 1976). ${ }^{14}$

For the purposes of gaining access to rural old age benefits, the burden of proving the engagement in rural activities was not too heavy. The law provided for several valid sufficient proofs for past rural activity, namely: individual labor contract or the Carteira de Trabalho $e$ Previdência Social; ${ }^{15}$ sharecropping or another tenancy agreement; statement by the local rural workers union co-signed by relevant authorities of the Judiciary Power; statement by the Judiciary; a proof of enrollment at the $\mathrm{INCRA}^{16}$ (Agrarian Reform and Colonization National Institute); documents produced by Social Security itself; and other means at the discretion of the social security administration. ${ }^{17}$

In the month of December of 1995 , RS 430 millions were paid out in rural benefits to $4,264,000$ beneficiaries, with an average benefit value of $\mathrm{R} \$ 100.76$ ( $\mathrm{R} \$ 0.96=\mathrm{US} \$ 1.00$ ). In this same month, $\mathrm{R} \$ 1,329$ millions were paid out in urban benefits to $5,159,000$ beneficiaries, with an average benefit value of $R \$ 257.37$.

Filgueiras (1998) cites numbers from the CONTAG (Brazilian Confederation of Workers in Agriculture) stating that in the Northeastern region approximately 500,000 age-eligible rural 
workers do not receive any benefit due to failure to produce the necessary documentation. This problem plagues especially the so-called bóias-frias, daily workers in seasonal jobs, usually with informal labor relations. In this same region, there were then 2,680,000 beneficiaries, which suggests a rough estimate of benefit take-up rates on the order of 5 out of 6 age-eligible elderly. In 1995, there were 822,322 rural beneficiaries in the 60-64 age group, for a rural population of 862,613 at the same age. A naive comparison yields take-up rates in the order of $95 \%$. However, rural residence is not a perfect measure of rural occupation, much less of past rural occupation. In that same year, there were 888,729 rural beneficiaries in the 65-69 age group, for a rural population of 733,993 at the same age, yielding a take-up rate of $121 \%$. Those numbers can be explained by either rural workers leaving the rural areas upon retirement or outright fraud in the benefit granting process. Anecdotal evidence emphasizes the incidence of excessive leniency in the process of granting rural pensions in the early nineties.

Delgado et alli (1999), in a survey of rural pension receivers in the Southern region, find that $51 \%$ of them live in urban areas. The decision of moving to the urban areas may be rationalized by, among other reasons: cities offering lower costs of goods consumed by the elderly (health care); better provision of public goods; savings in housing costs if the elderly move to houses of relatives or their children.

Adding up the information above, one can infer that take-up rates are high, probably greater than 3 out of 4 for the $60-64$ age group and probably more than $90 \%$ for the oldest old.

Appendix Figure 1 below shows median replacement rates for rural and urban male workers for both the South and the Northeast, arguably the regions with respectively the best and the worst living conditions in rural areas. Note the marked increase in replacement rates between 1989 and 1992 in rural areas in both regions. In contrast, replacement rates barely changed in urban areas, as expected. Although benefit values paid out to rural workers are low compared to benefits paid out to urban workers, it is important to emphasize the large replacement rates implied by the generalized rural poverty that characterizes some regions in Brazil. Downplaying the usual caveat about measurement errors in earning variables, replacement rates may have been as high as $180 \%$ for rural workers in the Northeastern region, where sub-minimum wages are not uncommon, at the aftermath of the increase in benefit values to one minimum wage. 
NE Urban

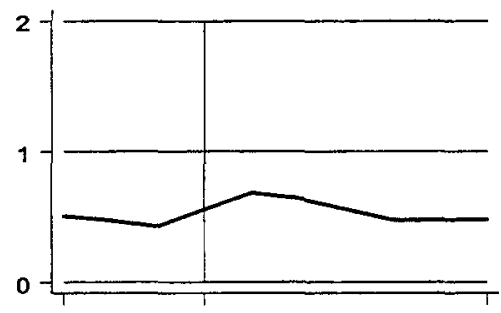

S Urban

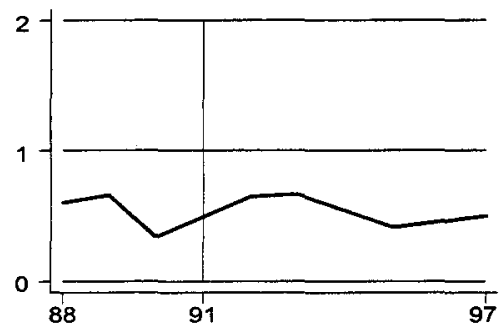

NE Rural

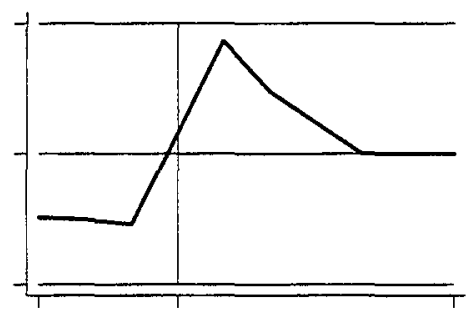

S Rural

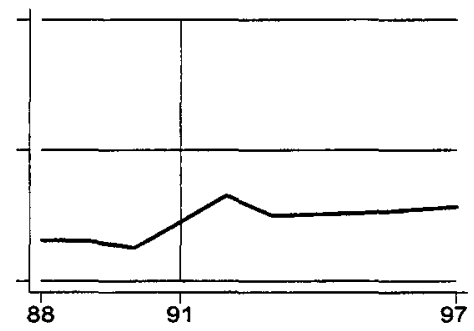

by Region and Rural/Urban Occupations Replacement Rates

Appendix Figure 1: The above figures show the time series for a measure of replacement rates, by occupations and regions, using the data from the PNAD. I calculate replacement rates by dividing mean positive social security benefits received by males age $60-70$ by the median earnings by males age $50-59$, the oldest 5-year cohort not eligible to old-age benefits. The vertical line in 1991 marks the increase in minimum benefits from $1 / 2$ to 1 minimum wage, binding for rural beneficiaries. The ratio of benefits to GDP per capita in Brazil is in the very high end of the cross-country distribution, 1.36 in 1989 (International Labor Organization). 


\section{Appendix B: Data Description}

The PNAD asks all respondents over age 10 whether they "worked"18 in the reference week. From this question I generate the labor supply measure did not work in the reference week.

Respondents who did not work in the reference week are asked if they dedicated themselves to activities in agriculture, fishing or animal creation for the subsistence of the persons living in the household. Respondents who asked this question negatively as well are asked if they dedicated themselves to activities of home or well building for their own household. Those who answer this question negatively as well are asked if they had any paid work they did not do because of vacation, strike, disease, bad weather or other reason.

The respondents who answered yes to any of the four sequential questions above are then asked how many trabalhos (jobs or activities, meaning both employment, self-employment or even home production activities) they had in the week of reference. The "number of trabalhos" question is top-coded at three. For the "main", "secondary" and "other" jobs, the respondents are asked about their total hours of work and monthly earnings, in both money and produce.

Another labor supply measure I analyze is the monthly earnings. Elderly males in Brazilian rural areas may work in unpaid activities whether in family agriculture or household production as an alternative to paid labor. I expect the differences between the results on "did not work in reference week?" and monthly earnings to be due to the nature of work in rural occupations, where self-employment and unpaid work at establishments owned by relatives are common occurrences.

Appendix Table 3 summarizes the means of the main variables of interest for different combinations of the variables "received positive benefits?" and "did not work reference week?", for both rural workers and the whole sample of males age 50-70. Respondents who did not work in the reference week report substantial smaller monthly earnings that the ones who worked. They are also more likely to be single, and if married, their spouses are on average older than the spouses of respondents who worked in the reference week. The variable "total hours of work per week" is also substantially smaller for respondents who did not work in the reference week. 


\section{Appendix Tables}

\section{Appendix Table 1}

QUANTITY OF RURAL BENEFITS OUTSTANDING BY AGE GROUPS

\begin{tabular}{|c|c|c|c|c|c|c|c|c|c|}
\hline \multirow[t]{2}{*}{ Age } & \multirow[t]{2}{*}{ Years } & \multicolumn{4}{|c|}{ Old Age } & \multicolumn{4}{|c|}{ Length-of-Service } \\
\hline & & Total & Males & Females & Ignored & Total & Males & Females & Ignored \\
\hline & 1992 & 77,737 & - & 77,651 & 86 & 35 & 32 & 3 & - \\
\hline \multirow[t]{6}{*}{ Up to 59} & 1993 & 321,969 & - & 321,907 & 62 & 161 & 139 & 22 & - \\
\hline & 1994 & 390,590 & - & 390,545 & 45 & 316 & 290 & 26 & - \\
\hline & 1995 & 329,434 & - & 329,395 & 39 & 715 & 681 & 34 & - \\
\hline & 1996 & 269,323 & - & 269,295 & 28 & 1,311 & 1,241 & 70 & - \\
\hline & 1997 & 247,767 & - & 247,739 & 28 & 2,101 & 1,992 & 109 & - \\
\hline & 1992 & 207,739 & 129,953 & 77,560 & 226 & 21 & 20 & 1 & - \\
\hline \multirow[t]{6}{*}{$60-64$} & 1993 & 635,750 & 326,158 & 309,403 & 189 & 86 & 84 & 2 & - \\
\hline & 1994 & 759,958 & 358,761 & 401,050 & 147 & 167 & 165 & 2 & - \\
\hline & 1995 & 726,863 & 303,424 & 423,327 & 112 & 304 & 299 & 5 & - \\
\hline & 1996 & 732,491 & 273,095 & 459,313 & 83 & 541 & 530 & 11 & - \\
\hline & 1997 & 723,857 & 251,349 & 472,444 & 64 & 738 & 723 & 15 & - \\
\hline & 1992 & 481,086 & 43,160 & 42,671 & 395,255 & 10 & - & - & - \\
\hline \multirow[t]{6}{*}{$65-69$} & 1993 & 656,280 & 180,417 & 196,941 & 278,922 & 15 & 1 & 1 & - \\
\hline & 1994 & 717,319 & 277,086 & 274,982 & 165,251 & 47 & 2 & 2 & - \\
\hline & 1995 & 747,754 & 360,973 & 320,682 & 66,099 & 88 & 2 & 2 & - \\
\hline & 1996 & 763,566 & 414,121 & 346,437 & 3,008 & 151 & 4 & 4 & - \\
\hline & 1997 & 811,452 & 433,553 & 377,730 & 169 & 242 & 5 & 5 & - \\
\hline & 1992 & $2,134,767$ & 2,604 & 14,951 & $2,117,212$ & 15 & 3 & 3 & 2 \\
\hline \multirow[t]{5}{*}{$70+$} & 1993 & $2,244,623$ & 12,587 & 77,800 & $2,154,236$ & 17 & 3 & 3 & 1 \\
\hline & 1994 & $2,336,111$ & 23,038 & 127,397 & $2,185,676$ & 15 & 3 & 3 & - \\
\hline & 1995 & $2,379,220$ & 35,646 & 166,496 & $2,177,078$ & 19 & 3 & 3 & - \\
\hline & 1996 & $2,409,301$ & 63,268 & 213,878 & $2,132,155$ & 24 & 4 & 4 & - \\
\hline & 1997 & $2,444,670$ & 134,928 & 271,691 & $2,038,051$ & 32 & 4 & 4 & - \\
\hline
\end{tabular}

Notes: Before 1991, the sex of the rural benefit recipient was not recorded in the DATAPREV computers. Therefore, the sex information for beneficiaries who applied before the cited date is labeled as ignored. I could not get access to any administrative figure available for the year of 1991. Source: Anuário Estatistico da Previdencia 
Appendix Table 2

RURAL PENSIONS OUTSTANDING, QUANTITIES AND VALUES

\begin{tabular}{|c|c|c|c|c|c|c|c|c|c|}
\hline \multirow[b]{2}{*}{ YEAR } & \multicolumn{4}{|c|}{ QUANTITIES } & \multicolumn{4}{|c|}{ AVERAGE VALUES } & \multirow[b]{2}{*}{ Min. Wage } \\
\hline & Total & LOS & Old Age & Disability & Total & LOS & Old Age & Disability & \\
\hline 1995 & $4,263,917$ & 1,128 & $3,787,195$ & 475,594 & $\mathrm{R} \$ 116.48$ & $R \$ 226.24$ & $R \$ 114.40$ & R\$133.09 & \\
\hline 1996 & $4,237,401$ & 2,026 & $3,769,648$ & 465,727 & $\mathrm{R} \$ 112.61$ & $\mathrm{R} \$ 283.43$ & RS112.56 & $\mathrm{R} \$ 112.19$ & $\mathrm{R} \$ 112.00$ \\
\hline 1997 & $3,932,128$ & 3,148 & $3,513,582$ & 415,398 & $\mathrm{R} \$ 121.37$ & $R \$ 321.04$ & $\mathrm{R} \$ 121.17$ & R\$121.55 & $\mathrm{R} \$ 120.00$ \\
\hline
\end{tabular}

Notes: LOS = Length-of-Service; Source: Anuário Estatístico da Previdência (1998)

Appendix Table 3

TABLE OF MEANS

FOR RURAL WORKERS AGE 50-70:

\begin{tabular}{|c|c|c|c|c|}
\hline SS Receiver? & Not SS Receiver & Not SS Receiver & SS Receiver & SS Receiver \\
\hline Worked Ref Week? & Did Not Work & Worked & Did Not Work & Worked \\
\hline Proportion & 4.30 & 68.46 & 8.17 & 19.07 \\
\hline Monthly Earnings & 55.32 & 411.08 & 11.31 & 291.14 \\
\hline Own Benefits Values & 0.00 & 0.00 & 201.73 & 191.68 \\
\hline Spouse' Benefit Values & 17.23 & 18.33 & 51.41 & 65.33 \\
\hline Total Hours of Work Per Week & 16.49 & 49.58 & 7.58 & 42.98 \\
\hline Single & 0.21 & 0.13 & 0.19 & 0.14 \\
\hline Spouse's Age if Married & 52.22 & 50.41 & 57.69 & 57.12 \\
\hline \multicolumn{5}{|c|}{ FOR ALL MALES AGE 50-70: } \\
\hline Proportion & 6.65 & 54.43 & 14.32 & 24.60 \\
\hline Monthly Earnings & 130.25 & 696.07 & 5.24 & 670.80 \\
\hline Own Benefits Values & 0.00 & 0.00 & 547.93 & 435.46 \\
\hline Spouse' Benefit Values & 44.49 & 40.07 & 102.34 & 92.23 \\
\hline Total Hours of Work Per Week & 12.14 & 48.25 & 1.16 & 43.33 \\
\hline Single & 0.24 & 0.12 & 0.17 & 0.12 \\
\hline Spouse's Age if Married & 51.59 & 49.66 & 55.95 & 54.96 \\
\hline
\end{tabular}

Source: PNAD 1989, 1990, 1992,1993 


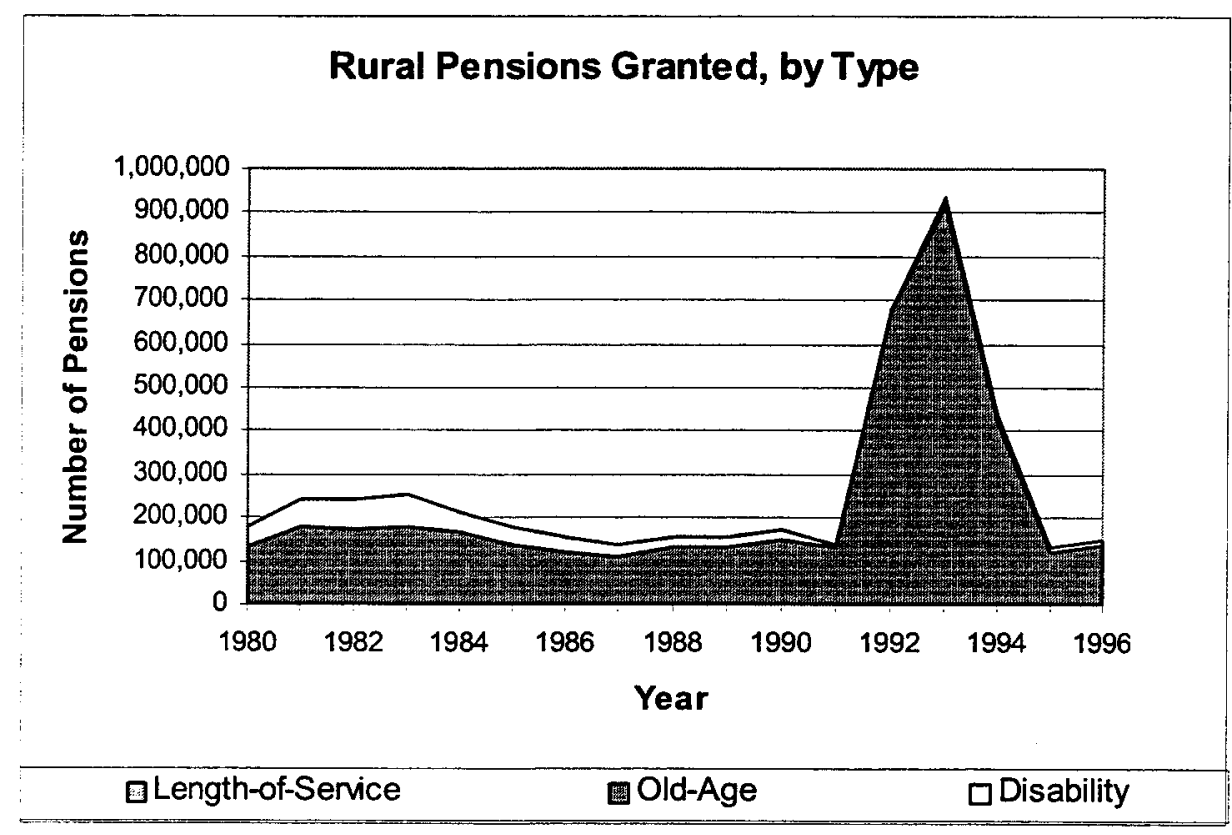

Figure 1: The graph above presents the flow of rural pensions granted for each year between 1980 and 1996. Notice that the spike starts in 1992 and lasts until 1994. The series displayed above aggregates data for males and females. Source: Anuário Estatístico da Previdência (1997). 

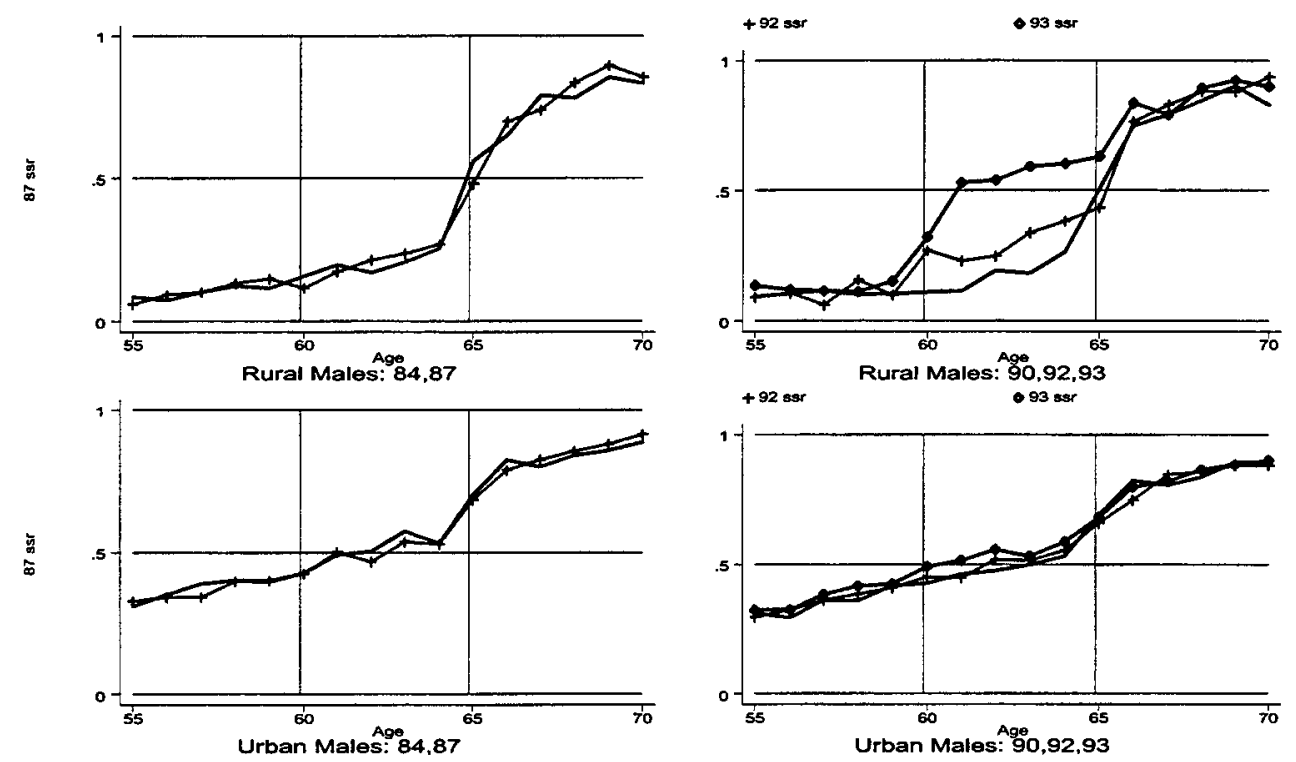

Male Benefit Take-up, in Rural and Urban Areas

Figure 2. The above figure shows age-benefit take-up profile for male rural and urban dwellers in the PNAD surveys of 1984, 1987, 1990, 1992 and 1993. The two graphs to the left show that there is no trend in the profiles using data from 1984 and 1987, previous to the reform. The graph in the upper right shows the gradual increase in benefit take-up rates between 1990 and 1993 for males age 60-64 living in the rural area. The graph in the lower right shows that little changed for urban dwellers. 

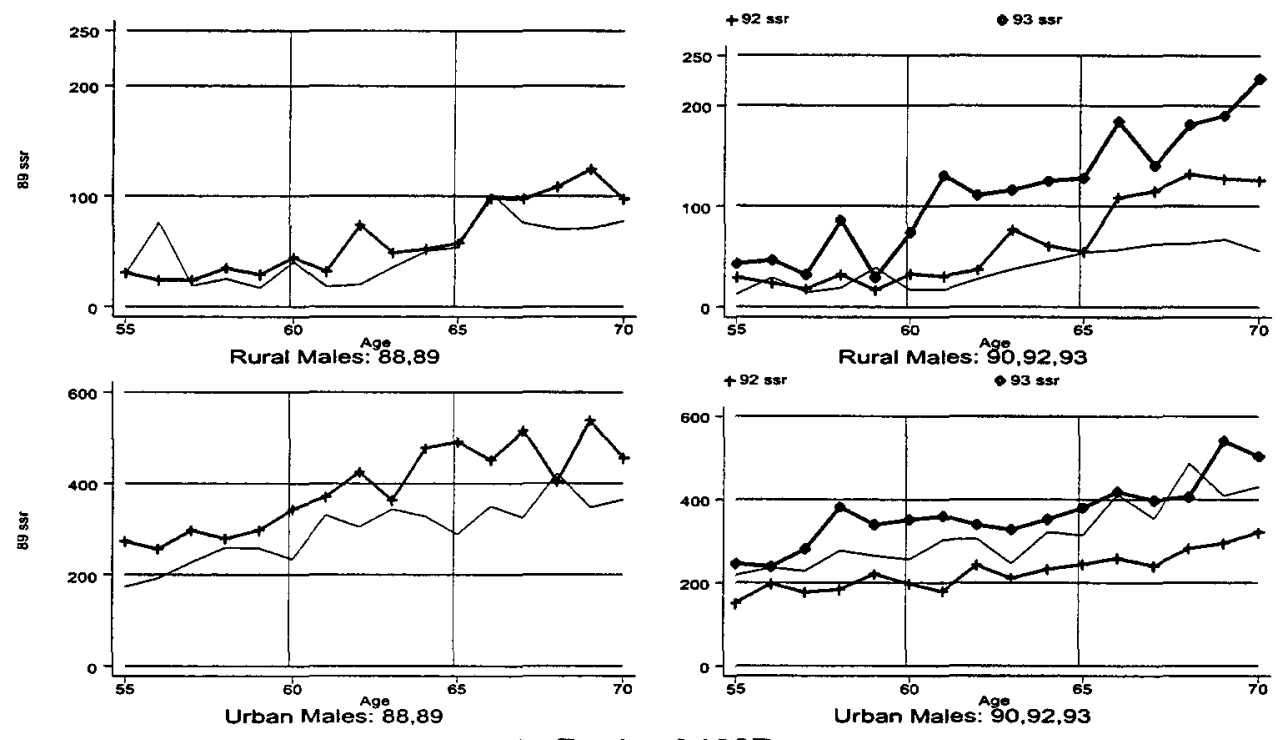

\section{Average Benefit Receipts, in Rural and Urban Areas}

Figure 3. The above figure shows age-average benefit receipts profiles for rural and urban dwellers in the PNAD survey of 1988, 1989, 1990, 1992 and 1993 in Reais of 1997. To construct the series above I purged the data from observations greater than the $99^{\text {th }}$ percentile of positive benefit receipts. In an attempt to purge the data from parallel shifts in the profiles due to lags and leads in price indexation, I adjusted the series as discussed in the Data Appendix. Notice the increase in average benefit receipt for rural dwellers age 60 and older in 1992 and especially 1993. Notice also the parallel character of other shifts in the age profiles found in the figures. 
${ }^{1}$ As cited in Kinsella and Martin (1994)).

${ }^{2}$ Meyer (1995), citing Cook and Campbell (1979), calls this problem "interaction of setting and treatment”.

${ }^{3}$ Case and Deaton (1998) show how a means tested program achieves the redistributive goal in South Africa.

${ }^{4}$ Hausman (1985).

${ }^{5} \mathrm{~A}$ beneficiary is required to stop working altogether only upon the receipt of disability benefits. Public sector workers are required to quit their jobs in order to receive benefits, and that is likely to have a stronger test than a private sector worker having to quit his job, for the specificity of work in the public sector.

${ }^{6}$ Unemployed and labor force non-participants are asked which occupation and at which industry they worked in the last year. In case they have not worked in the last year, they are asked to recall up to the last 4 years. Eligibility for nural old-age benefits requires that the worker had had rural occupations in 2 out of the last 3 years. Therefore, the questionnaire allows me to identify any worker potentially eligible to rural old-age benefits.

${ }^{7}$ Results based on those alternative specifications are available upon request.

${ }^{8}$ I do not restrict it only to single males because it would reduce sample size too much.

${ }^{9}$ I performed a pre-program test, as proposed by Heckman and Hotz (1989) and found strong evidence in favor of the identification strategy: triple differences estimates assuming that the reform occurred in a previous or later date show no effect on benefit take-up rates, monthly benefits or labor force variables. Similar reaffirming evidence is found when assuming that the reform affected other age groups. Results are available upon request.

${ }^{10}$ Parallel movements are likely caused by imperfect indexation of benefit values in high inflation environment. 
"In a preliminary version of this paper, I reported a substantial shift from wage earning to selfemployment. However, it may have been due to changes in the survey questionnaire with the same timing as the reform under study. Therefore, I do not emphasize those results.

${ }^{12}$ Railroad workers were the first group whose pressures were rewarded, in 1923, with the Lei Eloi Chaves.

${ }^{13}$ In this case, the means may justify the ends. Cynical observers place emphasis on the possibility of government control of peasant organizations as a motivation for the FUNRURAL's adopted organizational design.

${ }^{14}$ Other sources of historical information about Brazilian social security systems are Cardoso de Oliveira (1961) and Barroso Leite (1978).

${ }^{15}$ The Carteira de Trabalho e Previdência Social is an individual document where the holder's lifelong labor history should be registered. Every worker in the formal sector is supposed to have one.

${ }^{16}$ The Government institute responsible for agrarian reform and colonization of frontier lands.

${ }^{17}$ I do not have information about the most common documentation used by rural workers to apply for their old-age benefits, but anecdotal evidence suggests that rural workers unions supported the eligibility for the most destitute elderly, some of which did not even have birth certificates to prove their age.

${ }^{18}$ In this sentence, a trabalho (work) means a job or activity, comprising both employment and selfemployment activities. 
99985

B I BLIOTECA

MARIO HENRIOUE SIMONSEN

FUNDACĀO GETULLIO VARG^S

314899

9510312003

000314899

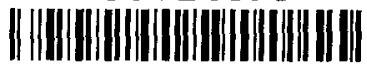

